Journal of Advanced College of Engineering and Management, Vol. 6, 2021

\title{
ANTHRACITE AS FILTER MEDIA IN FILTRATION PROCESS
}

\author{
Aashish Poudel ${ }^{1}$, I. M. Amatya ${ }^{2}$ \\ ${ }^{1}$ M. Sc.in Environmental Engineering, Institute of Engineering, Tribhuvan University \\ Pulchowk, Lalitpur, Nepal \\ Email: poudelaashish123@gmail.com \\ ${ }^{2}$ Assoc. Professor, Institute of Engineering, Tribhuvan University \\ Pulchowk, Lalitpur, Nepal
}

\begin{abstract}
This research was carried out to see the performance of anthracite as filter media infiltration process. The study also aimed to compare two filter media in terms of turbidity it removed, head loss development with time and filter run with increase in influent turbidity. Two rapid gravity filter(RGF) columns were prepared having internal dimensions of $11 \times 11 \times 290 \mathrm{~cm}^{3}$, one with anthracite and another with sand as filter media. The uniformity coefficient of sand and anthracite of 1.54 and 1.4 were maintained from sieve analysis. Constant Filtration rate of $3 \mathrm{~m} / \mathrm{h}$ was set and other ancillary activities were made same for both filter models. The experiments were repeated seven times with different influent turbidity ranges of 0-25,25-50,50100,100-150,150-200,200-250,250-300 NTU. Both the Filters were back washed with back washing velocity of $24 \mathrm{~m} / \mathrm{h}$, when the terminal head loss of $165.4 \mathrm{~cm}$ was obtained. The effluent quality of anthracite obtained was better for all the filter run. The head loss development with time was more for sand filter in all filter runs. The filter run time for sand vary from 150 to 8 hours and for anthracite, it varies from 172 to13hours from first to seventh filter run.
\end{abstract}

Keywords: efficiency, head loss, over burnt bricks, rapid gravity filter, sand, turbidity,

\section{Background}

Fast paced urbanization and industrialization have abruptly increased the demand of fresh water. Water resources all over the world are threatened not only by over exploitation and poor management but also by ecological degradation. Turbidity is a major problem found in Surface and Ground water. If not removed, turbidity can promote regrowth of pathogens in distribution systems, leading to waterborne disease outbreaks which have caused significant cases of gastroenteritis throughout the world (USEPA, 1999). Turbidity is the most practical measure of filter performance (Lusardi and Consonery, 1999)

Filtration is one of the most important steps in treating municipal water to clarify it, providing an important step in the protection of public health. Surface waters tend to be more turbid than ground waters, and contain more microbes, particles of vegetation, and silt. Filtration removes microbes and other suspended solids that could affect subsequent treatment processes.

Filtration using granular media such as quarried sand, anthracite and granular activated carbon is a well-known material used in both water and wastewater treatment. Crushed red brick is very good in removing total bacteria and turbidity (Matti, 2009) The application of crushed glass for filter media is relatively new and has been successfully applied as filter media for slow filtration by piccirillo and letterman in 1997 (Rutledge and Gagnon, 2002). Crushed glass can be an effective filter media in water filtration and a good alternative to silica sand in rapid filtration (Prakash, 2017). Sokolovic et al (2009) looked at the use of expanded polystyrene spheres for wastewater filtration (Devis, 2012). There was limited research available on novel media for use in rapid gravity filtration, and much of this was commercially orientated. The anthracite is also a novel media which resembles the desirables 
properties of filter media set by EPA. Anthracite can be crushed in to sizes as that of sand. Hence use of anthracite as filter media has been studied.

\section{Methodology}

The experiment was performed using two high rate filter columns made of fiberglass. One filter column was filled with sand and another with the anthracite as filter media. The procedure for research work was as follows:

Anthracite were collected from the Pulchowk Campus lab and were cleaned properly. The collected materials were crushed and were sieved through series of sieves, of sizes 2.0, 1.0, 0.6, 0.425 and $0.3 \mathrm{~mm}$. The materials retained on each sieve were collected separately and again cleaned to remove fine particles.

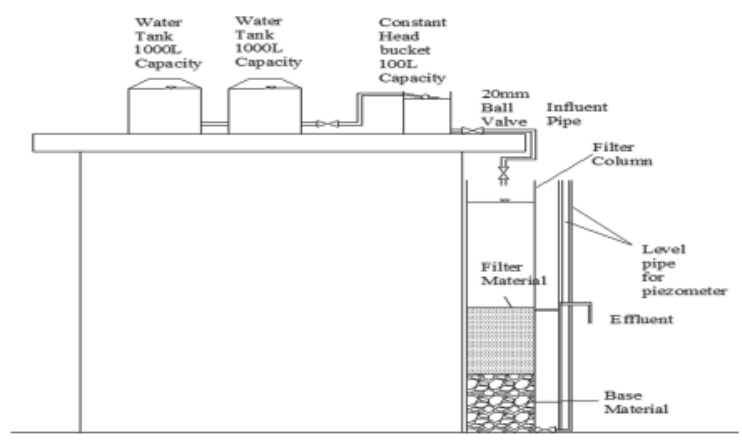

Figure 1: Model Setup

Internal dimensions of the filter were $11 \times 11 \times 290 \mathrm{~cm} 3$ each for both filter media. The raw water was stored in 2 HDPE tank having capacity of 1000 liters each. It was connected with constant head maintaining tank and further it was connected to filter models with $20 \mathrm{~mm}$ diameter pipes. Each model consists of altogether six ports as shown in Figure 1, three at $5 \mathrm{~cm}$ above the base of filter on three different faces for outlet, piezometer and backwashing purposes, fourth at height of $115 \mathrm{~cm}$ from base for piezometer, fifth at height of $135 \mathrm{~cm}$ from base for backwash effluent and sixth at height of $285 \mathrm{~cm}$ from base for influent overflow. Ball valve of $20 \mathrm{~mm}$ diameter is fitted to each port, except for the overflow port. The filter media and base material depth was kept as $60 \mathrm{~cm}$ and $50 \mathrm{~cm}$ respectively. Base material sizes used and depth of corresponding sizes is shown in Table 1.

Table 1: Base material (Gravel Thickness)

\begin{tabular}{|l|l|l|}
\hline Layer & Depth $(\mathrm{cm})$ & Size $(\mathrm{mm})$ \\
\hline Top layer & 15 & $2-6$ \\
\hline Intermediate layer & 15 & $6-12$ \\
\hline Intermediate layer & 10 & $12-20$ \\
\hline Bottom layer & 10 & $20-40$ \\
\hline Total & $50 \mathrm{~cm}$ & \\
\hline
\end{tabular}

Synthetic turbid water was made using previous sedimentation tank sludge. The mixing tank is stirred continuously by using mechanical rotor.

The filtration rate of $3 \mathrm{~m} / \mathrm{h}$ is kept constant by feeding the filter with constant discharge from top of filter column and effluent is taken out from outlet port elevated to height of $120 \mathrm{~cm}$ from base of filter with effluent valve opened completely. The resistance developed during filtration will be 
compensated by increase in water level above the filter media keeping the filtration rate constant throughout the filter operation.

For first experimental run, ground water from well was used as influent water and for remaining filter runs the artificial suspension was being prepared. Samples of influent and effluent water from both filters for various filter run were collected at interval of one hour in the sampling bottles of capacity $125 \mathrm{ml}$ and development of head loss was measured using piezometer.

The filter was operated intermittently and filter runs were terminated when the available head exhausted, irrespective of filter effluent turbidity value. The terminal head loss for both the filter media was set as $165.4 \mathrm{~cm}$. After exhaustion, filters were backwashed in order to remove the trapped solids in filter media with backwashing velocity of $24 \mathrm{~m} / \mathrm{hr}$. The end of backwashing operation was judged by viewing the clarity of backwash effluent. Further, the algae developed inside the filter columns and pipes are cleaned manually. In all filter runs, the methods used in the analysis are listed in Table 2

Table 2: Method of Analysis:

\begin{tabular}{|l|l|l|l|}
\hline S. No & Parameters & Methods & Frequency \\
\hline 1 & Turbidity & $\begin{array}{l}\text { Nephelometric Method } \\
\text { (2100 A Turbidity meter })\end{array}$ & Hourly \\
\hline 2 & Head Loss & Piezometer & Hourly \\
\hline 3 & Discharge & Volumetric Method & Daily \\
\hline
\end{tabular}

\section{Data Analysis}

The data was collected and recorded. Seven filter runs influent turbidity were 0-25, 25-50, 50100,100-150, 150-200, 200-250, 250-300 NTU respectively. The summary of anthracite filter and sand filter are shown in Table 3 and Table 4.

Table 3: Summary of filter runs for sand Filter

\begin{tabular}{|c|c|c|c|c|c|c|c|}
\hline \multirow[b]{2}{*}{$\begin{array}{l}\text { Filter } \\
\text { Run }\end{array}$} & \multirow{2}{*}{$\begin{array}{l}\text { Turbidity } \\
\text { Range, } \\
\text { NTU }\end{array}$} & \multirow{2}{*}{$\begin{array}{c}\text { Average } \\
\text { Influent } \\
\text { Turbidity, } \\
\text { NTU }\end{array}$} & \multirow{2}{*}{$\begin{array}{c}\text { Average } \\
\text { Effluent } \\
\text { Turbidity, } \\
\text { NTU }\end{array}$} & \multirow{2}{*}{$\begin{array}{c}\text { Filter } \\
\text { Run } \\
\text { Time, } \\
\text { Hrs }\end{array}$} & \multirow[b]{2}{*}{$\begin{array}{l}\text { UFRV, } \\
\mathrm{m} 3 / \mathrm{m} 2\end{array}$} & \multicolumn{2}{|c|}{ Filter Backwashing } \\
\hline & & & & & & $\begin{array}{l}\text { Time, } \\
\text { Mins }\end{array}$ & $\begin{array}{c}\% \text { Water } \\
\text { Consumption }\end{array}$ \\
\hline 1 & $0-25$ & 11.06 & 1.11 & 150 & 450 & 29 & 2.57 \\
\hline 2 & $25-50$ & 37 & 2.14 & 66 & 198 & 28 & 5.67 \\
\hline 3 & 50-100 & 74.64 & 4.46 & 37 & 111 & 27 & 9.7 \\
\hline 4 & $100-150$ & 126.67 & 6.67 & 22 & 66 & 25 & 15.11 \\
\hline 5 & $150-200$ & 167.33 & 6.36 & 15 & 45 & 23 & 20.3 \\
\hline 6 & $200-250$ & 216.3 & 7.18 & 15 & 45 & 28 & 24.82 \\
\hline 7 & $250-300$ & 273.93 & 7.39 & 8 & 24 & 27 & 44.88 \\
\hline
\end{tabular}


Table 4 Summary of filter runs for anthracite Filter

\begin{tabular}{|c|c|c|c|c|c|c|c|}
\hline \multirow{2}{*}{$\begin{array}{c}\text { Filter } \\
\text { Run }\end{array}$} & $\begin{array}{c}\text { Turbidit } \\
\text { y Range, } \\
\text { NTU }\end{array}$ & $\begin{array}{c}\text { Average } \\
\text { Influent } \\
\text { Turbidity, } \\
\text { NTU }\end{array}$ & $\begin{array}{c}\text { Average } \\
\text { Effluent } \\
\text { Turbidity, } \\
\text { NTU }\end{array}$ & $\begin{array}{c}\text { Filter } \\
\text { Run } \\
\text { Time, } \\
\text { Hrs }\end{array}$ & $\begin{array}{c}\text { UFRV, } \\
\text { m3/m2 }\end{array}$ & $\begin{array}{c}\text { Filter Backwashing } \\
\text { Mins }\end{array}$ & $\begin{array}{c}\text { \% Water } \\
\text { Consumption }\end{array}$ \\
\hline 1 & $0-25$ & 11.06 & 0.9 & 172 & 516 & 22 & 1.7 \\
\hline 2 & $25-50$ & 37 & 1.7 & 75 & 225 & 30 & 5.32 \\
\hline 3 & $50-100$ & 74.64 & 3.49 & 51 & 153 & 31 & 8.08 \\
\hline 4 & $100-150$ & 126.67 & 5.54 & 42 & 126 & 37 & 11.7 \\
\hline 5 & $150-200$ & 165.33 & 5.51 & 20 & 60 & 29 & 19.28 \\
\hline 6 & $200-250$ & 216.3 & 5.85 & 19 & 57 & 30 & 21 \\
\hline 7 & $250-300$ & 273.93 & 5.6 & 11 & 33 & 38 & 45.94 \\
\hline
\end{tabular}

\section{Filter run time with increase in influent turbidity}

Filter run length depends on the raw water characteristics. The filter run time for both the filter models subjected to different influent turbidity value is shown in Figure 2. with the increase in influent turbidity, filter run time decreases due to increase in suspended solid content in the water. Filter run time for both the filters were decreased with increase in turbidity.

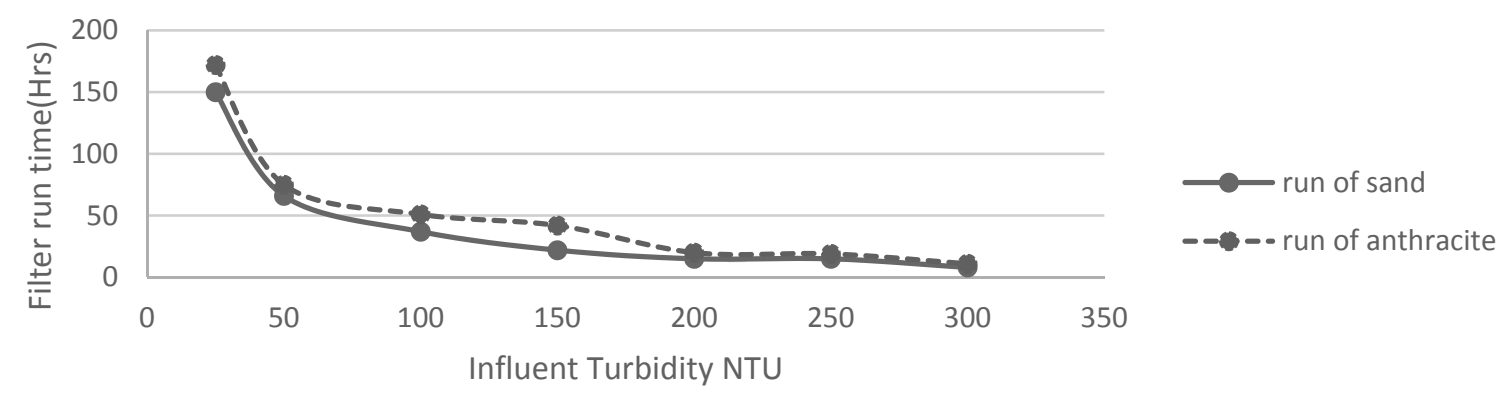

Figure 2: Filter run time with increase in influent turbidity

The maximum filter run time for sand filter was 150 hours and for anthracite filter was 172 hours, when both filters were subjected to influent turbidity of range 0 to 25 NTU or average influent turbidity of 11.06 NTU. The minimum filter run time for sand filter was 8 hours whereas for anthracite was 11 hours, when filters were subjected to influent turbidity of range 250 to $300 \mathrm{NTU}$ or average influent turbidity of 273.93 NTU. After Influent turbidity of 200 NTU there was approximately same filter run time. In all the filter run, anthracite filter showed longer run time than sand filter. 
Comparative analysis of turbidity removal with increase in influent turbidity

The comparative analysis of both filter media in removal of influent turbidity. The sand filter is comparatively lower efficient in removal of turbidity than anthracite filter. The anthracite filter is highly effective in removal of turbidity in range of 50 to 100 NTU and higher range of 250-300 NTU. In other ranges of turbidity, the removal capacity is moreover in same range but anthracite filter being in higher side. The comparative study shows that the anthracite filter media is very effective for turbidity removal in higher range of turbidity because the anthracite being more porous provides greater space for suspended particles resulting more filter run time. For both the filter media with the increase in influent turbidity the removal of turbidity is in increasing trend. The equation of the trend line for anthracite filter and sand filter respectively are shown as follows:

$$
\begin{aligned}
& y=0.0926 x+10.513 \\
& y=0.1192 x+12.553
\end{aligned}
$$

Eqn. (4.2)

The regression coefficient (R2) of sand is more than anthracite, which showed that data obtained for sand was more consistent as in Figure 3.

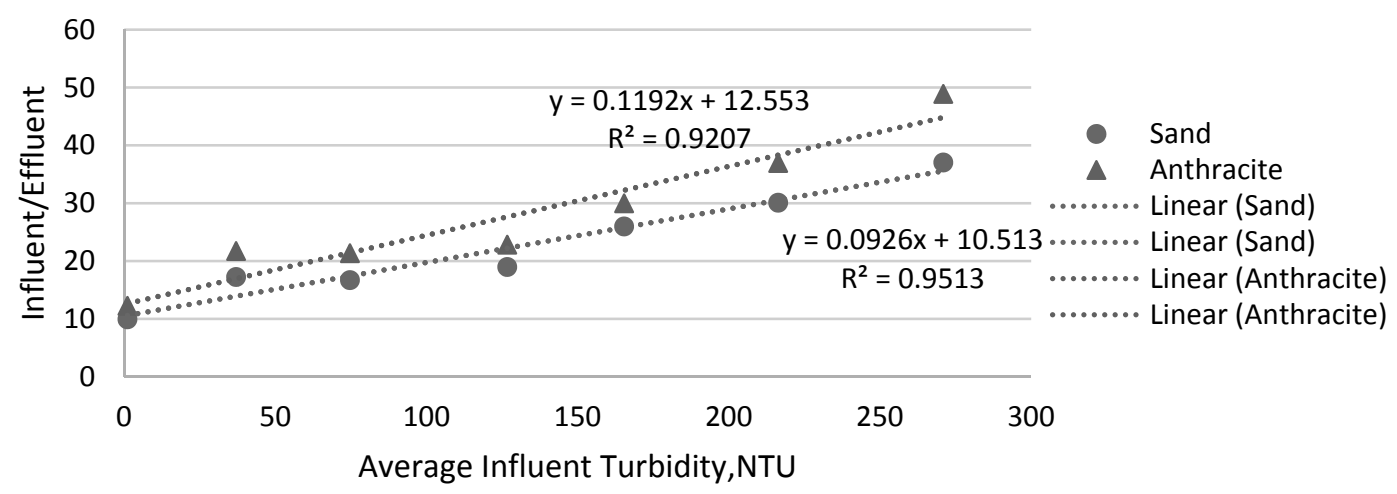

Figure 3: Comparative analysis of turbidity removal with increase in influent turbidity

\section{Conclusions}

This research was aimed to perform comparative study of two RSF, using filtration media of anthracite in one model and sand in another model. This research work also aimed to find out the usefulness of anthracite in filtration process. Based on the result obtained, following conclusions have been made:

i. Anthracite should not be treated as coal only but also should be used to treat turbid water with efficiency.

ii. Head loss development was most rapid for sand filter.

iii. Both the filter media had almost same turbidity removal efficiency. The average turbidity removal efficiency for sand was $94.76 \%$ and for anthracite was $95.76 \%$.

iv. In average, UFRV (Unit Filtration Rete Volume) for anthracite filter and sand filter was 167.14 and $134.14 \mathrm{~m}^{3} / \mathrm{m}^{2}$ respectively. 
v. Filter run length is inversely proportional to the influent turbidity. The maximum filter run time for anthracite filter was 172 hours and for sand filter was 150 hours for average influent turbidity of 11.06 NTU and minimum of 11 hours for anthracite filter and 8 hours for sand filter for average influent turbidity of 273.93 NTU.

\section{Recommendations}

The works which requires further study are recommended as:

1. It is recommended to study the microbiological as well as iron and manganese removal by anthracite.

2. The effect of porosity of anthracite in effluent and head loss development could be studied.

3. The pilot study was limited to direct filtration only. The effect of using coagulants on the effectiveness of anthracite filter could be studied.

4. This study was performed by making artificial turbidity in natural ground water. This research could be extended to waste water filtration.

5. The effectiveness of anthracite filter for higher filtration rates could be studied.

\section{Acknowledgement}

The authors are grateful to the MSc in Sustainable Water Sanitation Health and Development, Norwegian NOMA program, Pulchowk Campus, IOE, TU, Nepal for providing the part of the financial support necessary for this study. 


\section{References}

1. Joshi, C. R., 2017, "Comparative Study of Gravel and Anthracite as Filter Media in Up Flow Roughing Filter”, M. Sc. Thesis, Department of Civil engineering, Institute of engineering, Tribhuvan University, Pulchowk, Lalitpur.

2. Kansakar, B. R, 2015, “Water Supply Engineering”, First Edition, Divine Print Support, Lagan Tole, Kathmandu, Nepal, ISBN 978-0-7506-6843-9, pp. 201

3. Lusardi, P. J., and Consonery, P. J., 1999, "Factors affecting filtered water turbidity", JournelAWWA, 91(12), pp. 28.

4. Matti, L.Y., 2009, "Performance Comparison of Various Filters Media in Water Treatment", Tikrit Journal of Eng. Sciences, Vol.1, No.1, pp. 37,40.

5. Mayabi, A. O., Mutothia, F. U., and Kamau, G., 2009, "An Assessment of Soil Materials in Kenya as Sorbent Media for Defluoridation of Water", Journal of Civil Engineering Research and Practice, 6(2), pp. 39.

6. Mota, M. H., Chougule, S. H., and Bhosale, G. M., 2014, "Improvement of Performance of Rapid Sand Filter Using Coconut Shell as Capping Media", International Journal of Science and Research (IJSR), 3(6), pp. 2254.

7. NDWQS, 2062, "National Drinking Water Quality Standards”, Ministry of Physical Planning and Works, Kathmandu, pp.1.

8. Ngai, T., Dangol B., Murcott, S., and Shrestha, R.R., 2005. "Kanchan Arsenic Filter". Massachusetts Institute of Technology (MIT) and Environment and Public Health Organization (ENPHO). Kathmandu, Nepal.

9. Nobrega, P., 2010, "Demand Study and design of filtration tank", pp.43

10. NPC, 2015, "Sustainable Development Goals, 2016-2030 National (preliminary) Report", National Planning Commission, Kathmandu, Nepal, pp 78.

11. Peavy, H.S.,Rowe,D. R.,andTchobanoglous, G., 1985, "Environmental Engineering", Second Edition, McGraw-Hill. pp.178

12. Prakash, M., 2017,"Crushed glass as Filter Media in Water Filtration", M. Sc. Thesis, Department of Civil engineering, Institute of engineering, Tribhuvan University, Pulchowk, Lalitpur.

13. Purchas, D., and Sutherland, K., 2002, "Hand Book of Filter Media, Elsevier Science”, ISBN: 9780080507774, pp. 1. 